\title{
LABOUR CONTRIBUTION AND PRODUCTIVITY IN THE EUROPEAN UNION: A CLUSTER ANALYSIS
}

Jacek Batóg, Ph.D., Associate Prof.

University of Szczecin

Faculty of Economics and Management

Institute of Econometrics and Statistics

Mickiewicza 64, 71-101 Szczecin, Poland

e-mail: jacek.batog@usz.edu.pl

Received 15 July 2017, Accepted 9 October 2017

\begin{abstract}
The paper deals with an analysis of dynamics and the differentiation of basic features that characterize employment in European Union countries. The conducted research considered characteristics of the labour force such as the share of total labour compensation in the GDP, the number of hours worked and labour productivity. According to economic theory, this last variable plays a crucial role in the formation of the longterm economic growth. Also examined in the paper was the influence of the economic crisis on the behaviour of the indicated variables. A main statistical data source was the Total Economy Database published by the Conference Board. It can be seen from the results of the research that there exists growing international differences between the basic characteristics of labour force utilization and productivity. The conclusions were drawn on the grounds of a cluster analysis, which allowed deriving homogenous groups of countries according to the specificity of labour utilization and efficiency.
\end{abstract}

Keywords: labour force, productivity, cluster analysis, European Union

JEL classification: E24, J21, C38 


\section{Introduction}

Labour force resources and quality play a crucial role in economic growth as well as in the economic transition of countries. The relevance of labour depends on its main characteristics, including: share of labour in the national income, labour productivity and the number of hours worked. Since 1960 in major industrial countries it has been possible to observe a very large and systematic negative link between labour force growth and labour productivity (Beaudry, Collard, 2002). This relation is probably the main reason for the decreasing number of hours worked and reduction of the labour share in gross domestic product. We can also assume that the pattern of labour force use and efficiency is strongly related to the level of economic development.

The share of labour in national income has been one of the most important issues in economics and remains the focal point of modern economic theories. However, we can observe a serious disconnect between the use of this share in theoretical models and the actual estimates of this share in empirical investigations. Izyumov and Vahaly (2014) found in their study carried out in the 1990's and 2000's that labour shares in low developed and transition countries are respectively lower than in highly developed ones. Their data confirmed also the existence of a long-term downward trend for labour shares in the majority of countries ${ }^{1}$. Though, we will be able to see that this tendency was suppressed by the latest world economic crisis. Probably the main reasons for this phenomenon were lower profits and less investment possibilities. The drivers of decline of the labour share represented by wages, salaries and benefits in national income in almost all OECD countries were examined in (OECD, 2012). Authors' stressed the role played by factors such as increased productivity and capital-deepening, increased domestic and international competition, the reduction of workers' bargaining power, the evolution of collective bargaining institutions and reducing public ownership. The latest probably came about through the impact of privatisation on incentives for profit maximisation. According to their opinion, the decline of the labour share can result in greater income inequality, which might endanger social cohesion and slow down the current recovery. One of the key questions formulated in this study was: whether the decline of the aggregate labour share has been the result of a structural shift away from labour-intensive activities or whether instead it has been the result of a decline in the labour share within each industry? The results obtained using the shift-share method ${ }^{2}$ confirmed that within-industry falls in the labour share, i.e. divergence of industry-level productivities, explain an overwhelming proportion of its aggregate decrease

\footnotetext{
1 See also Kristal (2010).

2 Other application of a shift-share method in an analysis of the labour market can be found in Batóg and Batóg (2010).
} 
between 1990 and 2007. Despite similar levels of per capita income, education and technology, the development of labour income shares in OECD countries has displayed different patterns since $1960^{3}$. One of main reasons for this occurrence can be demography change which can affect the labour share, either by altering the intensity of the domestic capital, by causing factorbiased technological change or in a small open economy framework by creating a gap between domestic savings and investments. Empirical estimations with the use of a panel error correction model provide also evidence that increases in the expected retirement durations and old-age dependency ratios as well as declines in labour force growth rates have indeed been major forces behind the decline in labour shares that took place in many countries, especially in open economies (Schmidt, Vosen, 2013, pp. 357-361).

The findings of Hutchinson and Persyn (2012) suggest that lower trade costs and factors often associated with economic integration such as international low-wage competition and industry concentration have contributed to the decline in the labour share. One of the recent study conducted by Bassanini and Manfredi (2012) for 25 OECD countries, 20 business-sector industries and covering up to 28 years, indicated that total factor productivity growth and capital deepening jointly account for as much as $80 \%$ of the within-industry contraction of the labour share. They also found that other important factors are privatisation of state-owned enterprises and the increase in international competition as well as the off-shoring of intermediate stages of the production process. According to Sweeney (2012-2013) the decline in labour's share in GDP has contributed to increased inequality in the distribution of national income. He also pointed out the main reasons of this phenomenon: technology and policy changes, globalization, increased domestic and international competition, growing financialisation and sectoral shifts in employment. Other authors underline the impact of labour regulation (Deakin, Malmberg, Sarkar, 2014) or ageing (Schmidt, Vosen, 2013) on the labour share in national income.

The main goals of the undertaken research was an identification of the similarities of the European Union members according to specific chosen features of the labour force. The results were obtained by means of a cluster analysis.

\section{Recent trends in the European Union's labour force}

In the European Union we observed a decline in the share of total labour compensation in GDP from 1994 until $2007^{4}$ (from 62\% to almost 60\%). Due to the economic crisis and decline

\footnotetext{
3 See also Hogrefe and Kappler (2013), p. 303.

${ }^{4}$ See also OECD (2012), p. 113; Hogrefe, Kappler (2013), p. 305; Hutchinson, Persyn (2012), p. 18; Bassanini, Manfredi (2012), p. 8.
} 
of GDP there was a turning point in 2008-2009 (increase to 63.6\%) and redirect reduction in the next four years up to the level of 1994. The highest level of this share was indicated for Slovenia (84.0\% in 1994 and $71.8 \%$ in 2014), while the lowest was noticed for Slovakia (37.4\% in 1994 and $39.4 \%$ in 2014). There were also strong differences in changes of labour shares among European countries during the whole analysed period (see Figure 1).

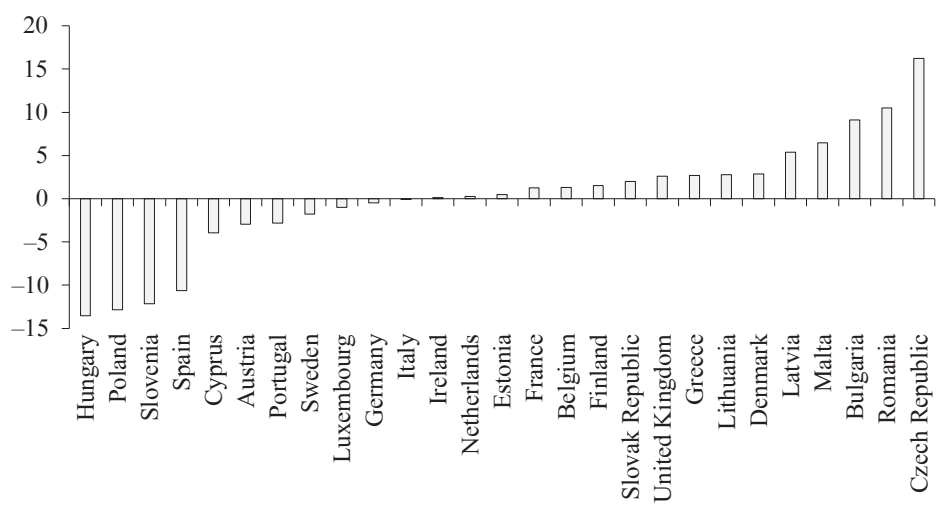

Figure 1. Changes of total labour compensation shares in GDP in the EU in 1994-2014 (\%)

Source: own calculations based on data from The Conference Board Total Economy Database ${ }^{\mathrm{TM}}$, May 2015.

We can observe that four countries were more competitive according to the relative cost of labour in 2014 in comparison to 1994: Hungary, Poland, Slovenia and Spain. We can assume that the main reason for this phenomenon was the lower dynamics of wages than the speed of economic growth.

Although, the proportion of labour in national income is quite significant for economic dynamics, the crucial role in economic development is played by labour productivity. Slowdown in productivity growth caused mainly by supply shocks, leads to the rise in labour shares, while the recovery of profit shares is by many authors interpreted as a result of the reaction of firms who increased profit shares by reducing labour demand and through a shift to more capitalintensive production techniques (Schmidt, Vosen, 2013, p. 358). There is a lot of literature concerning basic factors that influence labour productivity ${ }^{5}$. Some authors suggest that policies that promote investment, economic integration and international competitiveness improve short-run labour productivity, while in the long run; fixed capital accumulation is the dominant source of productivity improvements (Madden, Savage, 1998). Other researchers underline that

\footnotetext{
5 See for instance World Bank (2000) and Mućk (2015).
} 
in countries with high levels of labour costs and labour protection we can observe economic growth driven by labour productivity than a rise in the level of employment (Czyżewski, Łapińska-Sobczak, 2001, p. 530; Batóg, Batóg, 2007).

In 1994-2007 labour productivity in the European Union was rising in a very stable way, but this development path was stopped slightly by the last economic slowdown (see Figure 2). At the beginning as well as at the end of this period the highest level of labour productivity per employed person was observed for Luxembourg (respectively 128.1 thousand USD in 1994 and 128.7 thousand USD in 2014), while the lowest characterized Romania (respectively 18.3 thousand USD in 1994 and 45.2 thousand USD in 2014).

For all countries we have noticed a rise of productivity, but just the same as labour contribution, strong international differences in dynamics of labour productivity were visible. For instance for Luxembourg and Italy productivity rose accordingly by $0.43 \%$ and $1.20 \%$, whereas for Lithuania and Estonia this growth was equal respectively to $203.36 \%$ and $175.60 \%$. It is worth mentioning that the biggest growth of productivity was observed for new EU members and Ireland.

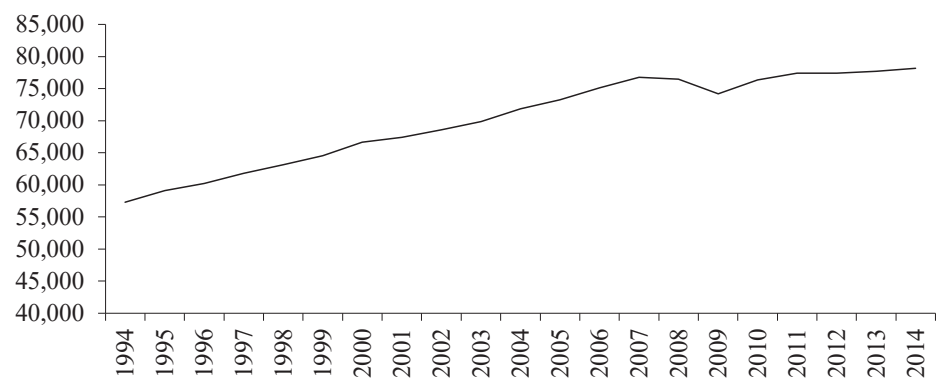

Figure 2. Labour productivity per employed person in the EU in 1994-2014 (2014 USD converted to 2014 price level with updated 2011 PPPs)

Source: own calculations based on data from The Conference Board Total Economy Database ${ }^{\mathrm{TM}}$, May 2015.

We can find some evidence that total weekly hours worked are positively correlated with the annual growth in GDP. The Monetary Policy Committee at the Bank of England pay close attention to the number of hours worked when considering monetary policy decisions as these may be more closely related to changes in demand and output than the level of employment (Stam, Coleman, 2010, p. 50). The growing negative correlation between labour productivity and annual hours worked per worker in EU countries means that, we cannot expect significant positive tendencies in the level of employment in the near future. Almost all European countries 
demonstrated the same decreasing evidence in annual hours worked per worker since 2001 (see Figure 3 to observe the average for the total in the EU).

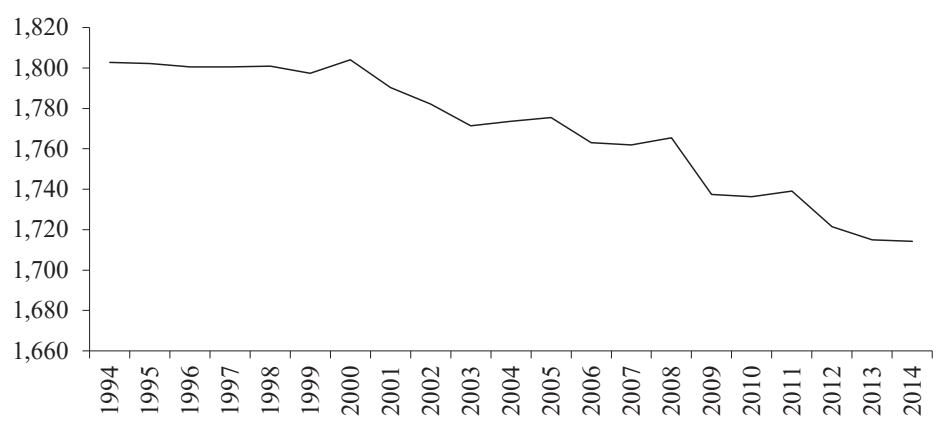

Figure 3. Annual hours worked per worker in the EU in 1994-2014

Source: own calculations based on data from The Conference Board Total Economy Database ${ }^{\mathrm{TM}}$, May 2015.

The biggest reductions were observed for Luxembourg $(-16.22 \%)$, Ireland $(-12.43 \%)$ and Malta $(-11.30 \%)$. There was only one essential exception - Lithuania - with growth equal to $5.38 \%$ (see Figure 4). The highest levels of annual hours worked per worker in 2014 were noticed for Greece $(2,042)$, Poland $(2,039)$, Malta $(1,994)$ and Latvia $(1,938)$, whereas the lowest was observed for Germany $(1,371)$ and Luxembourg $(1,378)$. It means that German and Luxembourg workers spent approximately 33\% fewer hours in work in comparison with such countries like Greece and Poland.

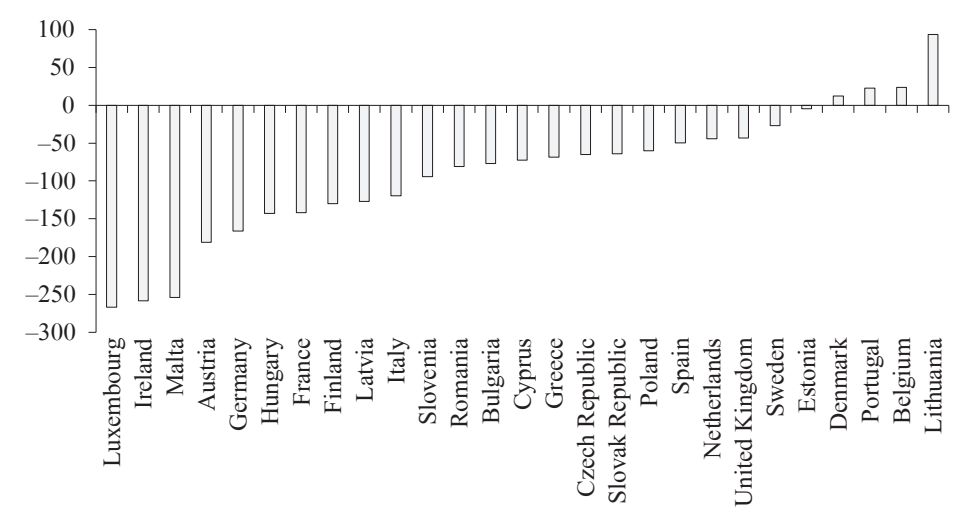

Figure 4. Change in annual hours worked per worker in the EU countries in 1994-2014

Source: own calculations based on data from The Conference Board Total Economy Database ${ }^{\mathrm{TM}}$, May 2015. 


\section{Classification of EU countries according to chosen features of the labour market}

The comparisons of labour characteristics such as productivity levels and share of labour compensation in GDP face several problems related to the measurement of labour input. Some countries integrate the measurement of labour input into their national accounts. In most countries, however, employment data are derived from labour force surveys, which are not entirely consistent with the national accounts. A second limitation is a consequence of the necessity of international comparisons of labour output which require price ratios to convert output expressed in a national currency into a common unit. One of the best databases that we can use in such circumstances is probably The Conference Board 2015, and The Conference Board Total Economy Database ${ }^{\mathrm{TM}}$.

All European Union countries, apart from Croatia because of the lack of data, were classified into homogenous groups according to all three variables described in the previous section. A cluster analysis (Ward's method) ${ }^{7}$ was applied to discover the path of the creation of two labour force profiles for EU countries in 1994-2014 ${ }^{8}$. The results were presented in figures 5-7. The first profile containing less developed countries (in 2014 new members of the EU, Greece, Portugal and Spain) is characterized by the low share of labour compensation in GDP, low labour productivity and high annual worked hours per worker. The second includes high developed European Union members with a high share of labour compensation in GDP, high labour productivity and low annual worked hours per worker (see Table 1).

When we look at the results of the cluster analysis received for Greece, Portugal and Spain we are not surprised. It is widely known that the structure and the behaviour of the economy observed in these countries were not so favourable for wages and productivity growth, especially during the last economic crisis.

Table 1. Labour force profiles for EU countries

\begin{tabular}{|l|l|}
\hline \multirow{2}{*}{$\begin{array}{l}\text { PROFILE } 1 \\
\text { Low GDP per capita }\end{array}$} & Low share of labour compensation in GDP (1994 mean 56.9; 2014 mean 57.7\%) \\
\cline { 2 - 2 } & Low labour productivity per person (1994 mean 38,508; 2014 mean 63,039) \\
\cline { 2 - 2 } PROFILE 2 & High annual worked hours per worker (1994 mean 1,920; 2014 mean 1,852) \\
\hline \multirow{2}{*}{ High GDP per capita } & High share of labour compensation in GDP (1994 mean 67.6; 2014 mean 66.9\%) \\
\cline { 2 - 2 } & High level of labour productivity per person (1994 mean 77,553; 2014 mean 94,515) \\
\cline { 2 - 2 } & Low annual worked hours per worker (1994 mean 1,676; 2014 mean 1,565) \\
\hline
\end{tabular}

Source: own calculations based on data from the Conference Board Total Economy Database ${ }^{\mathrm{TM}}$, May 2015.

\footnotetext{
${ }^{6}$ http://www.conference-board.org/data/economydatabase.

7 Description of this method could be found for example in Balicki (2009), pp. 276-279.

8 Exactly the same results were obtained by use of the k-means method.
} 


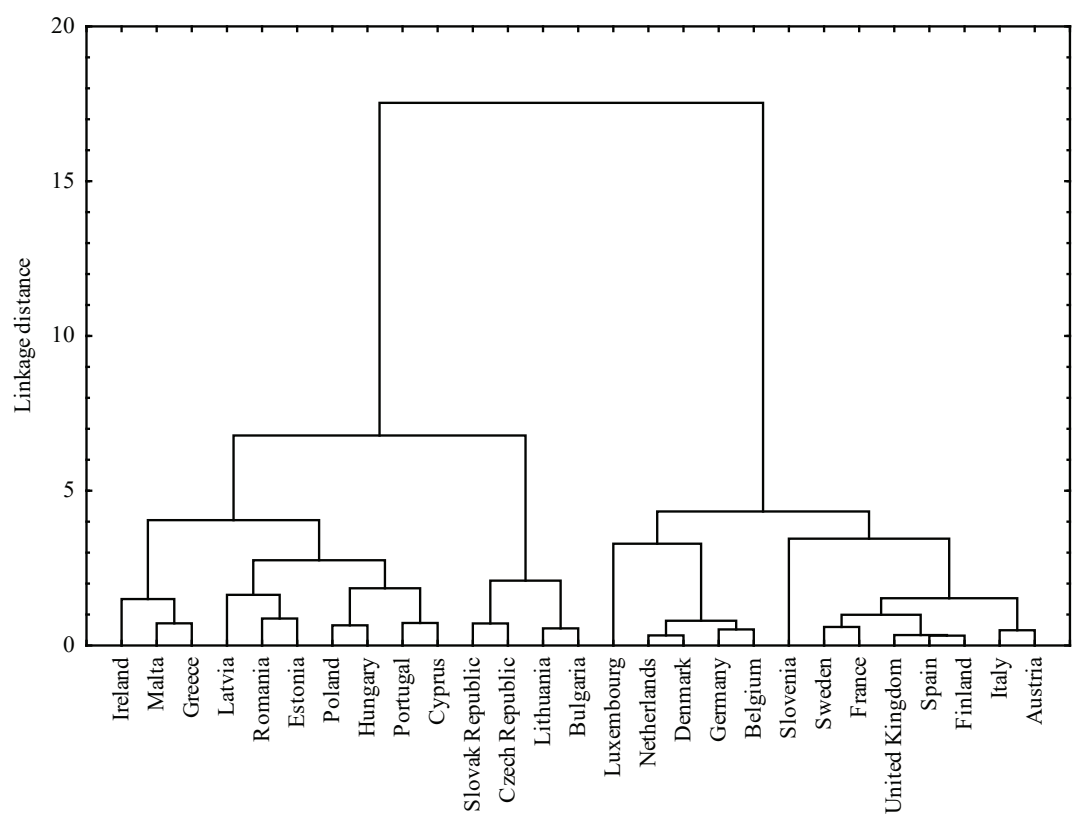

Figure 5. Results of a cluster analysis for 1994

Source: own calculations based on data from The Conference Board Total Economy Database ${ }^{\mathrm{TM}}$, May 2015.

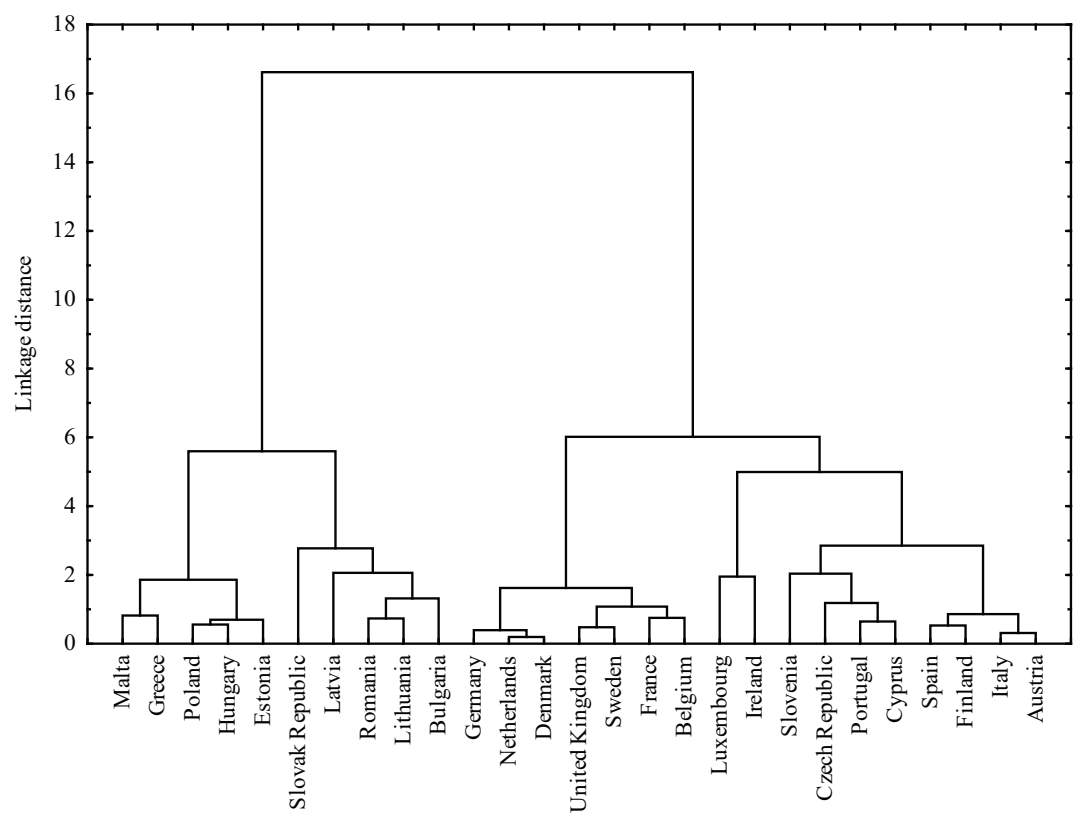

Figure 6. Results of a cluster analysis for 2004

Source: own calculations based on data from the Conference Board Total Economy Database ${ }^{\mathrm{TM}}$, May 2015. 


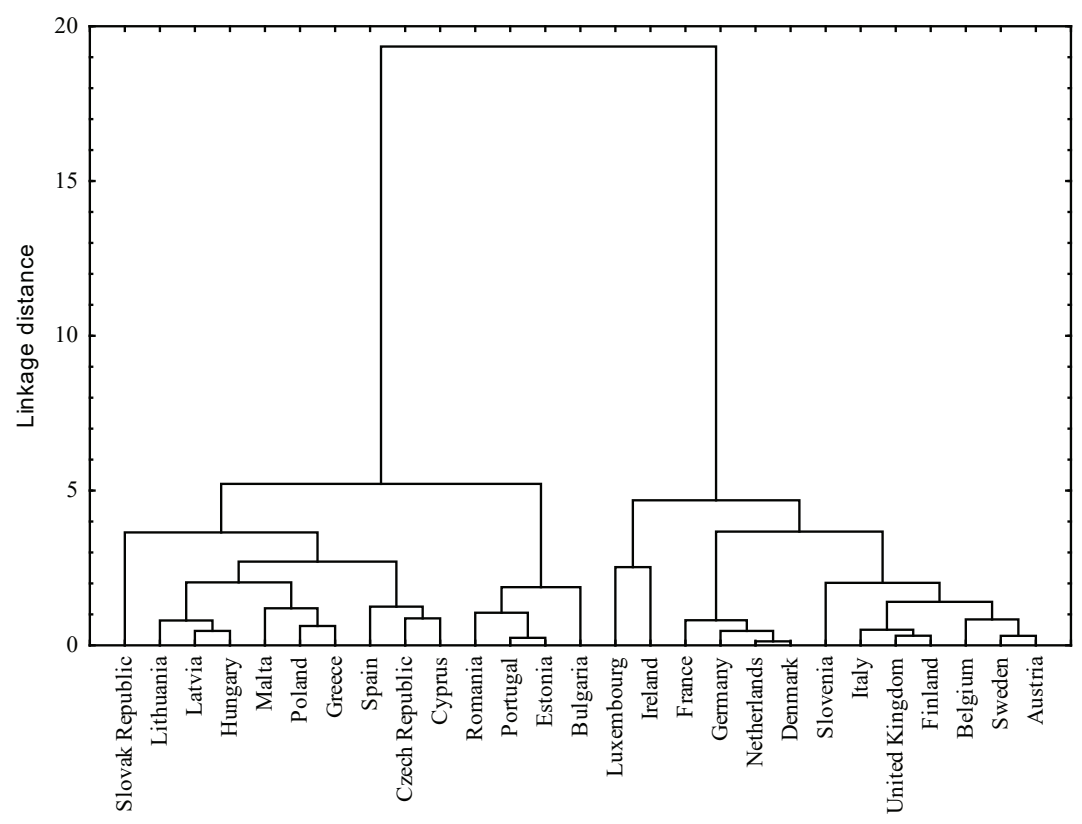

Figure 7. Results of a cluster analysis for 2014

Source: own calculations based on data from the Conference Board Total Economy Database ${ }^{\mathrm{TM}}$, May 2015.

In the analysed period both profiles were characterized by decreasing dispersion assessed by the measure of differentiation $Q$ :

where:

$$
Q=\sum_{r=1}^{k} \frac{1}{n_{r}} \sum_{i=1}^{n_{r}} d_{i c_{r}}
$$

$$
\begin{aligned}
& r \quad \text { group number }(r=1,2, \ldots, k), \\
& n_{r} \quad-\text { size of group } r, \\
& i \quad-\text { object number, } \\
& d_{i c_{r}} \text { - distance between object } i \text { and centroid of group } r .
\end{aligned}
$$

Table 2. Differentiation of profiles (Q) in 1994, 2004 and 2014

\begin{tabular}{|l|c|c|c|}
\hline \multirow{2}{*}{\multicolumn{1}{|c|}{ PROFILE }} & \multicolumn{3}{|c|}{ Year } \\
\cline { 2 - 4 } & 1994 & 2004 & 2014 \\
\hline PROFILE 1 & 1.362 & 1.258 & 1.136 \\
\hline PROFILE 2 & 1.068 & 1.005 & 0.973 \\
\hline Total & 2.430 & 2.263 & 2.109 \\
\hline
\end{tabular}

Source: own calculations based on data from the Conference Board Total Economy Database $^{\mathrm{TM}}$, May 2015. 
It means that countries within both groups become more homogenous, so we can observe some kind of club convergence for the main parameters of labour utilization. And we can derive a conclusion that despite the enlargement of the EU and the enhancement of labour force flows we can still observe two different labour markets for old and new members, with only some exceptions noticed for Greece, Portugal and Spain.

\section{Conclusions}

During the last few years we have been able to witness growing labour productivity, decreasing worked hours and a decreasing share of labour compensation in GDP in European Union countries. Especially this latter tendency should be considered as a key indicator by European governments. The main reason is that the shrinking importance of labour, may cause growing income inequalities. It could be visible first of all in ageing countries. Besides a decline in the share of total labour compensation in GDP there also exist strong differences in the changes of these shares among European countries. Although, there are indications that the decline in the labour share not necessarily is associated with lower unemployment but it can help to put the recovery from the global economic crisis on a more sustainable path, without extended fiscal deficits. Although labour productivity in the European Union has been growing now for several years, slightly lower because of the world economic slowdown, strong international differences in the dynamics of labour productivity have been observed. For all EU countries we have noticed also a decrease of annual hours worked per worker. The research results confirm also the growing similarities of the basic characteristics of the labour force of European countries unfortunately visible only separately for old and new members. It can become a crucial obstacle in obtaining the same structure of the economy and similar level of economic development for all European Union countries in the future. To provide such an interpretation we should be still aware that the applied method - Ward algorithm - is not robust for outliers, so in further research we can consider applying cluster analysis techniques based on positional measures like median or to remove non-typical observations. 


\section{References}

Balicki, A. (2009). Statystyczna analiza wielowymiarowa i jej zastosowania społecznoekonomiczne. Gdańsk: Wydawnictwo Uniwersytetu Gdańskiego.

Bassanini, A., Manfredi, T. (2012). Capital's Grabbing Hand? A Cross-Country/Cross-Industry Analysis of the Decline of the Labour Share. OECD Social, Employment and Migration Working Papers, No. 133. OECD Publishing (http://dx.doi.org/10.1787/5k95zqsf4bxt-en).

Batóg, J., Batóg, B. (2007). Productivity Changes in the European Union: Structural and Competitive Aspects. Folia Oeconomica Stetinensia, 1 (6), 63-74. DOI: 10.2478/v10031-0070005-4.

Batóg, J., Batóg, B. (2010). Employment Growth within BSR Countries: Some Predictive Aspects of Shift-share Analysis. In: J.W. Kramer, G. Prause, J. Sepp (eds.) in co-operation with Marcel Brätz, BMV, Baltic Business and Socio-Economic Development 2007, 3rd International Conference, Tallinn, Estonia, June 17-19, 2007 (pp. 671-682). Berlin: Berliner Wissenschafts-Verlag.

Beaudry, P., Collard, F. (2002), Why has the employment-productivity trade off among industrialized countries been so strong? NBER Working Paper Series, 8754. Cambridge: NBER.

Czyżewski, A.B., Łapińska-Sobczak, N. (2001). Zatrudnienie i bezrobocie a płace i koszty pracy w wybranych krajach Unii Europejskiej. Ekonomista, 4, 517-533.

Deakin, S., Malmberg, J., Sarkar, P. (2014). How do labour laws affect unemployment and the labour share of national income? The experience of six OECD countries, 1970-2010. International Labour Review, 1 (153), 1-27.

Hogrefe, J., Kappler, M. (2013). The labour share of income: heterogeneous causes for parallel movements? The Journal of Economic Inequality, 3 (11), 303-319. DOI: 10.1007/s10888012-9221-8.

Hutchinson, J., Persyn, D. (2012). Globalisation, concentration and footloose firms: in search of the main cause of the declining labour share. Review of World Economics, 1 (148), 7-43. DOI: 10.1007/s10290-011-0112-z.

Izyumov, A., Vahaly, J. (2014). Recent trends in factor income shares: a global perspective. Journal of Economic Studies, 5 (41), 696-707.

Kristal, T. (2010). Good Times, Bad Times: Post-war Labour's Share of National Income in Capitalist Democracies. American Sociological Review, 5 (75), 729-763. DOI:10.1177/0003122410382640.

Madden, G., Savage, S.J. (1998). Sources of Australian labour productivity change: 1950-1994. Economic Record, East Ivanhoe, 74 (227), 362-372. 
Mućk, J. (2015). O średniookresowych własnościach dynamicznych udziału wynagrodzenia czynników wytwórczych w PKB. Rozprawa doktorska, promotor J. Growiec. Warszawa: SGH w Warszawie.

OECD Employment Outlook 2012 (2012). Labour Losing to Capital: What Explains the Declining Labour Share?, pp. 109-161.

Schmidt, T., Vosen, S. (2013). Demographic change and the labour share of income. Journal of Population Economics, 1 (26), 357-378. DOI: 10.1007/s00148-012-0415-y.

Stam, P., Coleman, J. (2010). The relationship between hours worked in the UK and the economy. Economic \& Labour Market Review, 9 (4), 50-54.

Sweeney, P. (2012-2013). Presidential Address. An Inquiry into the Declining Labour Share of National Income and the Consequences for Economies and Societies. Journal of the Statistical and Social Inquiry Society of Ireland, XLII, 109-129.

World Bank (2000). The Quality of Growth. New York: Oxford University Press. 